\title{
Z Score Estimation for Indian Banking Sector
}

\author{
Roli Pradhan
}

\begin{abstract}
From traditional times the $Z$ score values have been constantly used for prediction of Bankruptcy. This has been vital to both the lenders and investors whose returns are based on solvency estimates. The terms of credit have gone a $U$ turn from the traditional times to the modern scenario today. The basic concern of prediction is to evaluate the terms of credit and ensure repayment safely. $Z$ score has been used as a tool to evaluate the credibility of the firms. This paper provides the $\mathrm{Z}$ score value for the public sector banks. This value is useful when these banks demand loans from the RBI or any other funding agency. The usage of back propagation neural network is to forecast the internal parameters of $Z$ score and then use these internal parameters to forecast the $Z$ score value up to 2020. Thus the paper emphasizes the usage of BPNN for prediction of bankruptcy for public sector banks in India.
\end{abstract}

Index Terms-Bankruptcy, internal parameters of $\mathrm{Z}$ score Prediction, $\mathbf{Z}$ score value.

\section{INTRODUCTION}

Looking into the scenario of business today the enhancing uncertainty scenario takes away the surety of existence from firms. Perhaps to be sure of the longevity of the firm becomes the prime issue of concern by all the business houses. The viability of banks holds prime importance as it relates to financial investments, funding, capacity building and expansion by ploughing back profits. $\mathrm{Z}$ score has been used as a tool to evaluate the credibility of the firms. This paper provides the $\mathrm{Z}$ score value for the public sector banks. This value is useful when these banks demand loans from the RBI or any other funding agency. The usage of back propagation neural network is to forecast the internal parameters of $\mathrm{Z}$ score and then use these internal parameters to forecast the $\mathrm{Z}$ score value up to 2020 . Thus the paper emphasizes the usage of BPNN for prediction of bankruptcy for public sector banks in India. The research focus on three banks that are considered in the big, medium and small capital norms being Oriental Bank of Commerce, Punjab National Bank and State Bank of India. The paper is divided into sections. Section I gives the introduction about the research done in the paper, Section II discusses the bankruptcy scenario related to Z score, Section III describes the model design and methodology, Section IV discusses the BPNN Model application in Z Score for Public Sector banks in India, Section $\mathrm{V}$ evaluates the predictions of internal parameters of $\mathrm{Z}$ score, Section VI brings forth the findings and the last Section VII sums up the research.

Manuscript received May 24, 2014; revised August 26, 2014.

Roli Pradhan is with the Department of Management, NITTTR, Bhopal (e-mail: pradhanroli@gmail.com.)

\section{LITERATURE SURVEY}

Several researches have been conducted in the area. O'Leary [1] argues that prediction of bankruptcy probably is one of the most important business decision-making problems affecting the entire life span of a business, failure results in a high cost from the collaborators (firms and organizations), the society and the country's economy [2]. Over the last 35 years, the topic of company failure prediction has developed to a major research domain in corporate finance [3]-[5]. Academic researchers from all over the world have been developing a gigantic number of corporate failure prediction models, based on various types of modeling techniques [6]. Besides the classic crosssectional statistical methods, which have produced numerous failure prediction models, researchers have also been using several alternative methods for analyzing and predicting business failure [7], [8]. To date, a clear overview and discussion of the application of alternative methods in corporate failure prediction is still lacking. Research has shown that most business failure is caused by bad or poor management [9]. This could be in the form of inexperienced management styles, fraud, and rapid technological changes amongst other variables. Financial failure may take the form of bankruptcy or insolvency [10], [11]-[14]. Bankruptcy refers to a condition where the total liabilities exceed the fair value of assets. Financial statements are normally used to gauge the performance of the firm and its management [15]. The financial statements commonly used are profit and loss statement, balance sheet and cash flow statements. From the financial statements, various ratios can be calculated to assess the current performance future prospects of the concerned firm [16], [17]. Some of the ratios used include current ratio, quick ratio, and working capital to total debt, total debt to total assets, profit margin to sales and return on total assets. Perhaps the best way to avoid failure is to examine the myriad explanations for business failure [18] [19]. Studies carried out by Altman [20] used financial ratios to predict occurrence of bankruptcy and he was able to predict $94 \%$ correctly one year before bankruptcy occurred and $72 \%$ two years before its actual occurrence. Dimitras, Koksal, and Kale [21] pointed out that after 30 years of research on this topic. There is no generally accepted model for business failure prediction that has its basis in a causal specification of underlying economic determinants. Because of the confusingly varied and restrictive assumptions underlying these classic statistical models, there is need to recourse to alternative methods.

Prior empirical studies of failure have concentrated almost exclusively on financial ratio data, though other studies of failure usually cite managerial variables as being critical. The usefulness of ratio-based business failure 
prediction models has been questioned. For example, ElZayaty [22] find ratio models to be poor predictors of bankruptcy of 132 businesses predicted to fail, and only 5 were discontinued over a five-year period. Ohlson JA indicates that qualitative data can provide at least as good predictions as traditional financial ratios. In Kenya, a study on business failure prediction was done using discriminate analysis. Kiragu [23] did another study on the prediction of corporate failure using price adjusted accounting data. Kogi [24] did an analysis of the discriminant corporate failure prediction model based on stability of financial ratios. Altman is known for the development of the Z-score formula, which he published in 1968. The Z-score for predicting Bankruptcy is a multivariate formula for a measurement of the financial health of a company and a powerful diagnostic tool that forecasts the probability of a company entering bankruptcy within a 2 year period. Studies measuring the effectiveness of the Z-score [25], [26] have shown that the model has $70 \%-80 \%$ reliability. The $\mathrm{Z}$ score analysis has been the base for research in this paper.

\section{DESIGN AND Methodology}

In this paper, a two step methodology has been adopted. The part A provides the steps formulated for the prediction of internal parameters of $\mathrm{Z}$ score, followed by part B which enlists the steps followed for the prediction of $\mathrm{Z}$ score using back propagation neural networks.

\section{A. Formulation of Internal Parameters of Z Score Paper Size}

The basic ratios are formulated from details mentioned in published statements like balance sheet, cash flow statements, yearly details of banks, profit and loss statements obtained from CMIE database, Reserve Bank of India. Data is also taken from the official websites of the banks and financial institutions and the internet. Consequently this research work uses financial data i.e. published time series data for the last 11 years from 2000 to 2009.

1) (Current Assets-Current Liabilities )/Total Assets

2) Retained Earnings/ Total Assets.

3) EBIT/ Total Assets

4) Equity/Total Liabilities

\section{B. Prediction of $Z$ Score Internal Parameters Using BPNN}

1) Catering to Neural Network inputs

2) Tolerance level Minimization

3) Data convergence using Neural Networks

4) Formulation of Absolute error

5) Prediction of ratios in each Ratios pillar

6) Data Validation

\section{Altman Z Score Formula}

$\mathrm{T} 1=($ Current Assets-Current Liabilities $) /$ Total Assets

$$
\mathrm{T} 2=\text { Retained Earnings } / \text { Total Assets }
$$

T3 = Earnings before Interest and Taxes / Total Assets T4 = Book Value of Equity / Total Liabilities
Z-Score Bankruptcy Model:

$$
\mathrm{Z}=6.56 \mathrm{~T} 1+3.26 \mathrm{~T} 2+6.72 \mathrm{~T} 3+1.05 \mathrm{~T} 4
$$

Zones of Discrimination:

$$
\begin{gathered}
\mathrm{Z}>2.6 \text {-"Safe" Zone } \\
1.1<\mathrm{Z}<2.6 \text {-"Grey" Zone } \\
\mathrm{Z}<1.1 \text {-"Distress" Zone }
\end{gathered}
$$

\section{BPNN MODEL APPLICATION IN Z SCORE FOR PUBliC SECTOR BANKS IN INDIA}

The market capitalisation suggests certain that banks have been predominantly capturing markets. Here three of them have been selected for $\mathrm{Z}$ score analysis and forecasting. These are Oriental Bank of Commerce, Punjab National Bank and State Bank of India. The basic input sheets for all the internal parameters are formulated for the three specified banks in India. The process of input ratio formulation uses the book formulae for computation of the ratios, which will further be used as input parameters for Artificial Neural Network. The Altman Z-score prediction uses the Neural Network (1, 5, and 4). The number if input rows are 1 . The hidden layers are 5 and the outcomes are 4 internal

\begin{tabular}{|c|c|c|c|c|c|}
\hline \multirow{2}{*}{$\begin{array}{l}\text { Public } \\
\text { Sector } \\
\text { Banks }\end{array}$} & \multirow[t]{2}{*}{ Time } & \multicolumn{4}{|c|}{ Input Parameters } \\
\hline & & $\begin{array}{l}\text { CA- } \\
\text { CL)/ } \\
\text { Total } \\
\text { Assets }\end{array}$ & $\begin{array}{c}\text { Retained } \\
\text { Earnings/ } \\
\text { Total } \\
\text { Assets }\end{array}$ & $\begin{array}{c}\text { EBIT/ } \\
\text { Total } \\
\text { Assets }\end{array}$ & $\begin{array}{c}\text { Equity/ } \\
\text { Total } \\
\text { Liabilities }\end{array}$ \\
\hline \multirow[t]{7}{*}{ OBC } & 2001 & 0.943326 & 0.04565 & 0.11216 & 0.007112 \\
\hline & 2002 & 0.924254 & 0.042033 & 0.109782 & 0.005968 \\
\hline & 2003 & 0.936343 & 0.041991 & 0.113615 & 0.005665 \\
\hline & 2004 & 0.93354 & 0.046744 & 0.098214 & 0.004695 \\
\hline & 2005 & 0.913661 & 0.045946 & 0.070938 & 0.003561 \\
\hline & 2006 & 0.909643 & 0.053183 & 0.074808 & 0.003267 \\
\hline & 2007 & 0.921352 & 0.066547 & 0.074801 & 0.003389 \\
\hline \multirow[t]{7}{*}{ PNB } & 2001 & 0.865784 & 0.038987 & 0.081279 & 0.003921 \\
\hline & 2002 & 0.862777 & 0.041978 & 0.080515 & 0.003342 \\
\hline & 2003 & 0.870653 & 0.047153 & 0.076046 & 0.003639 \\
\hline & 2004 & 0.881733 & 0.051326 & 0.068712 & 0.003077 \\
\hline & 2005 & 0.872751 & 0.073619 & 0.062138 & 0.003081 \\
\hline & 2006 & 0.863976 & 0.06938 & 0.055071 & 0.002498 \\
\hline & 2007 & 0.894067 & 0.067643 & 0.056393 & 0.00217 \\
\hline \multirow[t]{7}{*}{ SBI } & 2001 & 0.73659 & 0.049465 & 0.077749 & 0.002013 \\
\hline & 2002 & 0.781807 & 0.046565 & 0.077392 & 0.001667 \\
\hline & 2003 & 0.791241 & 0.047891 & 0.075746 & 0.001511 \\
\hline & 2004 & 0.796349 & 0.052424 & 0.064382 & 0.0014 \\
\hline & 2005 & 0.805242 & 0.057737 & 0.061314 & 0.001291 \\
\hline & 2006 & 0.837653 & 0.058967 & 0.058853 & 0.001144 \\
\hline & 2007 & 0.827194 & 0.061765 & 0.062825 & 0.001066 \\
\hline
\end{tabular}
parameters. The input point is time and output has been the required ratios. The period for input has been from 20002008 which has been normalized from 1 to 8 . The details of the internal ratios and the values are enlisted in the Table I.

A Backpropogation Neural Network has been used to transfer data sets. Trained network is used for prediction of ratios for the forthcoming two years being 2008, 2009, and 2010. The initial weights of the neural paths were in the range of -0.02 to 0.05 . Convergence study of neural network was carried out for difference tolerance error of $1,0.75,0.5,0.4,0.3,0.2,0.1,0.01,0.001$. The predicted values 
obtained from the neural network were compared with the actual field data or the arithmetic computation done from the published statements. The Table II provides the convergence details for the internal parameters of $\mathrm{Z}$ score.

TABLE II: CONVERGENCE DETAILS FOR INTERNAL PARAMETERS OF Z-SCORE

\begin{tabular}{|c|c|c|c|c|c|c|c|c|c|c|c|}
\hline \multirow{2}{*}{$\begin{array}{l}\text { Public } \\
\text { Sector } \\
\text { Banks } \\
\end{array}$} & \multirow[t]{2}{*}{ Tolerance } & \multirow[t]{2}{*}{ Ratios } & \multicolumn{3}{|c|}{2008} & \multicolumn{3}{|c|}{2009} & \multicolumn{3}{|c|}{2010} \\
\hline & & & Actual & Predicted & \%Error & Actual & Predicted & \%Error & Actual & Predicted & \%Error \\
\hline \multirow[t]{5}{*}{ OBC } & 0.001 & $\begin{array}{c}\text { CA-CL)/ } \\
\text { Total } \\
\text { Assets } \\
\end{array}$ & 0.9248 & 0.9284 & -0.3926 & 0.9283 & 0.9305 & -0.234 & 0.9548 & 0.9305 & 2.5420 \\
\hline & & $\begin{array}{c}\text { Retained } \\
\text { Earnings/ } \\
\text { Total } \\
\text { Assets } \\
\end{array}$ & 0.0590 & 0.0665 & -12.809 & 0.0491 & 0.0665 & -35.58 & 0.0451 & 0.0665 & -47.4605 \\
\hline & & $\begin{array}{c}\text { EBIT/ } \\
\text { Total } \\
\text { Assets }\end{array}$ & 0.0769 & 0.0673 & 12.5202 & 0.0882 & 0.0689 & 21.841 & 0.0834 & 0.0733 & 12.1179 \\
\hline & & $\begin{array}{c}\text { Equity/ } \\
\text { Total } \\
\text { Liabilities }\end{array}$ & 0.0028 & 0.0036 & -30.189 & 0.0022 & 0.0036 & -63.70 & 0.0018 & 0.0036 & -99.2469 \\
\hline & & Z Value & 6.7790 & 6.8847 & -1.5605 & 6.8445 & 6.9164 & -1.049 & 6.9728 & 6.9237 & 0.7033 \\
\hline \multirow[t]{5}{*}{ PNB } & 0.1 & $\begin{array}{c}\text { CA-CL)/ } \\
\text { Total } \\
\text { Assets } \\
\end{array}$ & 0.89899 & 0.8759 & 2.56394 & 0.88504 & 0.8755 & 1.0778 & 0.89033 & 0.87512 & 1.70739 \\
\hline & & $\begin{array}{c}\text { Retained } \\
\text { Earnings/ } \\
\text { Total } \\
\text { Assets } \\
\end{array}$ & 0.06445 & 0.0639 & 0.78576 & 0.06444 & 0.0652 & -1.269 & 0.06446 & 0.06631 & -2.87319 \\
\hline & & $\begin{array}{c}\text { EBIT/ } \\
\text { Total } \\
\text { Assets }\end{array}$ & 0.07405 & 0.0637 & 13.9209 & 0.08573 & 0.0618 & 27.851 & 0.07572 & 0.06008 & 20.65577 \\
\hline & & $\begin{array}{c}\text { Equity/ } \\
\text { Total } \\
\text { Liabilities } \\
\end{array}$ & 0.00194 & 0.0025 & -30.526 & 0.00158 & 0.0024 & -51.78 & 0.00128 & 0.00228 & -78.9296 \\
\hline & & Z Value & 6.60706 & 6.3522 & 3.85628 & 6.59373 & 6.3477 & 3.7309 & 6.56082 & 6.34370 & 3.30935 \\
\hline \multirow[t]{5}{*}{ SBI } & 0.01 & $\begin{array}{c}\text { CA-CL)/ } \\
\text { Total } \\
\text { Assets } \\
\end{array}$ & 0.8352 & 0.8205 & 1.7491 & 0.8104 & 0.8218 & -1.402 & 0.8353 & 0.8228 & 1.4948 \\
\hline & & $\begin{array}{c}\text { Retained } \\
\text { Earnings/ } \\
\text { Total } \\
\text { Assets } \\
\end{array}$ & 0.0854 & 0.0650 & 23.9487 & 0.0794 & 0.0676 & 14.834 & 0.0677 & 0.0700 & -3.3350 \\
\hline & & $\begin{array}{c}\text { EBIT/ } \\
\text { Total } \\
\text { Assets } \\
\end{array}$ & 0.0748 & 0.0594 & 20.5561 & 0.0791 & 0.0589 & 25.599 & 0.0635 & 0.0586 & 7.7366 \\
\hline & & $\begin{array}{c}\text { Equity/ } \\
\text { Total } \\
\text { Liabilities } \\
\end{array}$ & 0.0011 & 0.0010 & 6.0949 & 0.0009 & 0.0010 & -15.64 & 0.0007 & 0.0010 & -51.2262 \\
\hline & & Z Value & 6.2630 & 6.0365 & 3.6177 & 6.1298 & 6.0484 & 1.3269 & 6.2630 & 6.0583 & 3.2683 \\
\hline
\end{tabular}

TABLE III: PREDICTED VALUES FOR INTERNAL PARAMETERS OF Z-SCORE

\begin{tabular}{|c|c|c|c|c|c|c|}
\hline \multirow[t]{2}{*}{ Public Sector Bank } & \multirow[t]{2}{*}{ Tolerance } & \multirow[t]{2}{*}{ Years } & \multicolumn{4}{|c|}{ Output for Internal Parameters } \\
\hline & & & $\begin{array}{c}\text { (CA-CL)/ } \\
\text { Total } \\
\text { Assets }\end{array}$ & $\begin{array}{c}\text { Retained } \\
\text { Earnings/ } \\
\text { Total } \\
\text { Assets }\end{array}$ & $\begin{array}{c}\text { EBIT/ } \\
\text { Total } \\
\text { Assets }\end{array}$ & $\begin{array}{c}\text { Equity/ } \\
\text { Total } \\
\text { Liabilities }\end{array}$ \\
\hline \multirow[t]{12}{*}{ OBC } & \multirow[t]{12}{*}{0.001} & 2009 & 0.93163 & 0.06600 & 0.06822 & 0.00370 \\
\hline & & 2010 & 0.93180 & 0.06655 & 0.07204 & 0.00376 \\
\hline & & 2011 & 0.93166 & 0.06655 & 0.07500 & 0.00382 \\
\hline & & 2012 & 0.93154 & 0.06600 & 0.07697 & 0.00387 \\
\hline & & 2013 & 0.93145 & 0.06680 & 0.07829 & 0.00391 \\
\hline & & 2014 & 0.93139 & 0.06700 & 0.07923 & 0.00395 \\
\hline & & 2015 & 0.93135 & 0.06710 & 0.07992 & 0.00397 \\
\hline & & 2016 & 0.93128 & 0.06721 & 0.08321 & 0.00404 \\
\hline & & 2017 & 0.93121 & 0.06737 & 0.08509 & 0.00408 \\
\hline & & 2018 & 0.93115 & 0.06753 & 0.08698 & 0.00413 \\
\hline & & 2019 & 0.93108 & 0.06768 & 0.08886 & 0.00417 \\
\hline & & 2020 & 0.93101 & 0.06784 & 0.09074 & 0.00422 \\
\hline \multirow[t]{4}{*}{ PNB } & \multirow[t]{4}{*}{0.1} & 2009 & 0.87560 & 0.06541 & 0.06167 & 0.00239 \\
\hline & & 2010 & 0.87520 & 0.06652 & 0.05975 & 0.00226 \\
\hline & & 2011 & 0.87483 & 0.06742 & 0.05792 & 0.00214 \\
\hline & & 2012 & 0.87451 & 0.06814 & 0.05622 & 0.00203 \\
\hline
\end{tabular}




\begin{tabular}{|c|c|c|c|c|c|c|}
\hline & & 2013 & 0.87423 & 0.06872 & 0.05466 & 0.00193 \\
\hline & & 2014 & 0.87398 & 0.06919 & 0.05324 & 0.00184 \\
\hline & & 2015 & 0.87378 & 0.06957 & 0.05196 & 0.00177 \\
\hline & & 2016 & 0.87338 & 0.07058 & 0.05000 & 0.00164 \\
\hline & & 2017 & 0.87307 & 0.07127 & 0.04838 & 0.00153 \\
\hline & & 2018 & 0.87277 & 0.07195 & 0.04676 & 0.00143 \\
\hline & & 2019 & 0.87247 & 0.07263 & 0.04514 & 0.00132 \\
\hline & & 2020 & 0.87216 & 0.07332 & 0.04351 & 0.00122 \\
\hline SBI & 0.01 & 2009 & 0.82233 & 0.06815 & 0.05891 & 0.00102 \\
\hline & & 2010 & 0.82336 & 0.07064 & 0.05875 & 0.00100 \\
\hline & & 2011 & 0.82422 & 0.07277 & 0.05876 & 0.00099 \\
\hline & & 2012 & 0.82495 & 0.07457 & 0.05885 & 0.00098 \\
\hline & & 2013 & 0.82557 & 0.07606 & 0.05899 & 0.00097 \\
\hline & & 2014 & 0.82611 & 0.07730 & 0.05915 & 0.00096 \\
\hline & & 2015 & 0.82657 & 0.07831 & 0.05929 & 0.00095 \\
\hline & & 2016 & 0.82753 & 0.08070 & 0.05927 & 0.00094 \\
\hline & & 2017 & 0.82822 & 0.08238 & 0.05934 & 0.00093 \\
\hline & & 2018 & 0.82892 & 0.08406 & 0.05942 & 0.00092 \\
\hline & & 2019 & 0.82962 & 0.08574 & 0.05950 & 0.00090 \\
\hline & & 2020 & 0.83032 & 0.08743 & 0.05958 & 0.00089 \\
\hline
\end{tabular}

TABLE IV: Z-SCORE VALUE FOR SAMPLE BANKS FROM 2009-2020

\begin{tabular}{|c|c|c|c|c|c|c|c|c|c|c|c|c|c|}
\hline Banks & 2008 & 2009 & 2010 & 2011 & 2012 & 2013 & 2014 & 2015 & 2016 & 2017 & 2018 & 2019 & 2020 \\
\hline $\mathrm{OBC}$ & 6.679 & 6.651 & 6.6502 & 6.6 & 6.746 & 6.621 & 6.725 & 6.7525 & 6.791 & 6.774 & 6.7569 & 6.739 & 6.722 \\
\hline PNB & 6.5070 & 6.541 & 6.526 & 6.340 & 6.336 & 6.533 & 6.4831 & 6.4291 & 6.300 & 6.270 & 6.241 & 6.211 & 6.181 \\
\hline SBI & 6.263 & 6.1105 & 6.1298 & 6.0418 & 6.053 & 6.0629 & 6.0715 & 6.0788 & 6.0511 & 6.0443 & 6.06375 & 6.0307 & 6.0239 \\
\hline
\end{tabular}

\section{BPNN MODELING ANALYSIS, RESULTS AND OUTCOMES}

The validation was carried out for all the internal parameters of Z-score value. The Z-score internal parameter estimates were considered from 2001 to 2008 were applied to train the backpropagation neural network and subsequently estimates of the year 2009 to 2013 the data values were used for validation. Based on these values predictions were drawn using BPNN from 2011 to 2020. These values have then been substitutes in the Z-score formula for market credits to compute the Z-score values from 2009 to 2020. The market has witnessed several ups and downs during the period 2005 and 2010 and the modelled. The trained BPNN has been able to forecast the Z-score values in approximation to the actual values suggesting that the BPNN has the ability to forecast the Zscore parameters financial ratios. Table III provides details of the percentage error at the adopted level of tolerance.

\section{OBSERVATION AND FINDINGS}

The validation was carried out for all the internal parameters of Z-score value. The Z-score internal parameter estimates were considered from 2001 to 2007 were applied to train the backpropagation neural network and subsequently estimates of the year 2008 to 2013 the data values were used for validation. Based on these values predictions were drawn using BPNN from 2011 to 2015.these values have then been substitutes in the Z-score formula for market credits to compute the $\mathrm{Z}$-score values from 2008 to 2020. The market has witnessed several ups and downs during the period 2005 and 2010 and the modelled BPNN has been able to closely predict the Z-score values from 2005 to 2010 . The trained BPNN has been able to forecast the Z-score values in approximation to the actual values suggesting that the BPNN has the ability to forecast the Z-score parameters financial ratios.

\section{A. Computation of Z Score Value}

As already mentioned the Altman Z-score forms a benchmark model within this research because of that reason this Z-score model utilizes the formula of market credits being variables depicted. The internal values computed above are utilized in computation of the Z-score value. The independent parameters are independent variables and have to be multiplied by the coefficients already mentioned and the $\mathrm{Z}$-score value is computed. The details of formula used have been mentioned in earlier section of this paper. Table IV provides the details of the $\mathrm{Z}$ score values of different banks.

The $\mathrm{Z}$ score reveals that it is safe to lend to the three banks as the $\mathrm{Z}$ values obtained lie in the safe Zone. The norms of credit can also be relaxed as their sustainability in the market is been confirmed by the $\mathrm{Z}$ value. For OBC bank the movement of $\mathrm{Z}$-score has been from $0.1 \%$ to $4.6 \%$. The trend exhibited by the predicted value is from $0.6 \%$ to $7.8 \%$. For PNB bank the movement of Z-score has been from $0.2 \%$ to $3.1 \%$. The trend exhibited by the predicted value is from $0.2 \%$ to $3 \%$. For SBI bank the movement of Z-score has been from $0.4 \%$ to $5.1 \%$. The trend exhibited by the predicted value is from $0.1 \%$ to $3 \%$. 


\section{B. Graphical Representation of Z Score of Banks}

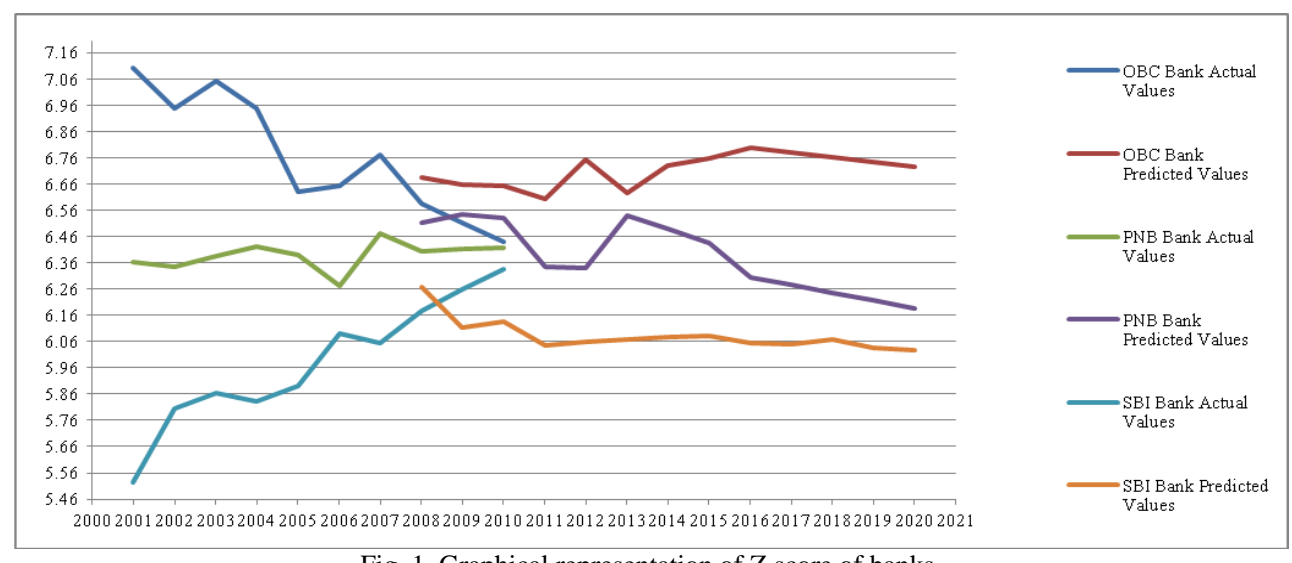

Fig. 1. Graphical representation of $\mathrm{Z}$ score of banks.

\section{CONCLUSION}

The analysis suggests that the $\mathrm{Z}$ score value of Oriental Bank of Commerce is the highest amongst the mentioned three banks. The priority lending must be done in the order OBC, PNB and then SBI. The state of banks has improved from 2011 onwards. The scenario has been progressive and stable. The tailored BPNN is found to be of immense utility at the time of predicting the viability of lending to any firm. The obtained $\mathrm{Z}$ score validation suggests that the neural network can predict closely. The tailored back-propagation neural network endeavours to predict the internal parameters of a firm to regulate the bankruptcy and assess the credit viability when a bank requires credit and can also be utilized to plan the periods of recovery of the lent amount. For the analysis, different combinations of short-term debts and long-term debts as a proxy for a firm's liabilities to examine whether the liquidity constraint from short-term liabilities alone actually forces firms to declare bankruptcy, or if we should consider that the amount of long-term debts is also relevant to determining a firm's bankruptcy probability.

\section{REFERENCES}

[1] E. G. O'Leary, Business Failure Prediction and the Efficient Market Hypothesis, Simon Fraser University, November 2001.

[2] B. S. Ahn, S. S. Cho, and C. Y. Kim, "The integrated methodology of rough set theory and artificial neural network for business failure prediction," Expert Systems with Applications, vol. 18, pp. 65-74, 2000.

[3] M. Argenti, Financial Ratios as Predictors of Failure, Empirical Research in Accounting: Selected Studies, University of Chicago, Chicago, pp. 71-111, 2003.

[4] Beaver and H. William, "Market Prices, financial ratios, and the prediction of failure," Journal of Accounting Research, pp. 179-192, Autumn 1968.

[5] A. F. Bilanas and F. Harris, "A methodology predicting failure in the construction Industry," Journal of Construction Management and Economics, vol. 13, no. 3, pp. 189-196, 2004.

[6] J. H. Aldrich and F. D. Nelson, "Linear probability, logit and probit models," Sage Beverly Hills, Calif, 2007.

[7] E. B. Eidleman, "A discriminant analysis of predictors of business failure," Journal of Accounting Research, Spring, Institute of Professional Accounting, Chicago, Ill, pp. 167-179, 2007.

[8] P. Keige, Business Failure Prediction Using Discriminate Analysis, University of Nairobi, 1991.

[9] E. I. Ahn, "Financial Ratios, Discriminant Analysis and the Prediction of Corporate Bankruptcy," Journal of Finance, pp. 589-609, 2000

[10] H. Bruton, K. Wan, and A. Ahlstrom, "The effects of acquisitions on the market value of the banking sector: An empirical analysis from Greece," European Journal of Scientific Research (EJSR), vol. 24, issue 3, 2008.
[11] S. M. Bryant, "A case-based reasoning approach to bankruptcy prediction Modeling," Intelligent System Accounting, Financial and Management, vol. 6, pp. 195-214, 1997.

[12] P. Carrol and R. T. Nelson "How to Recognize and Avoid Organizations' Decline," Sloan Management Review, pp. 41-46, Spring 2008.

[13] J. K. W. Charitou, C. M. Tam, and R. K. C. Cheung, "Construction firms at the crossroads in Hong Kong, Engineering," Construction and Architectural Management, vol. 12, no. 2, pp. 111-124, 2000.

[14] K. Charitou, "How stock prices react to managerial decisions and other profit signalling events, in the Greek mobile telecom market?" in Proc. 3rd International Conference on Applied Financial Economics, Samos Island, 2002.

[15] J. A. Ohlson, "Financial ratios and the probabilistic prediction of bankruptcy," Journal of Accounting Research, vol. 18, no. 1, pp. 109$131,1980$.

[16] R. O. Milkette, "An empirical test of financial ratio analysis for small business failure prediction," Journal of Financial Quantitative Analysis, University of Washington, Seattle, pp. 1477-1493, Mar. 2001.

[17] G. L. V. Millihni, Predicting the Possibility of Failure in a Canadian Firm, Simon Fraser University, 2003.

[18] A. Robbins and L. Pearce, "Corporate bankruptcy prediction models applied to emerging economies: Evidence from argentina in the years 1991-1998," International Journal of Commerce and Management, vol. 17, no. 4, pp. 295-311, 2005

[19] E. G. L. V G. Sands, Springate, and V. Turgut, "Predicting business failures," CGA Magazine, pp. 24-27, 2001.

[20] E. I. Altman, "Financial ratios, discriminant analysis, and prediction of corporate bankruptcy," Journal of Finance, vol. 23, no. 4, pp. 589610, 2003.

[21] D. Dimitras, A. Koksal, and S. Kale, "Business failures in the construction industry, engineering," Construction and Architectural Management, vol. 7, no. 2, pp. 120-132, 2006.

[22] W. El-Zayaty, "Financial ratios as predictors of failure, empirical research in accounting: selected studies, supplement," Journal of Accounting Research, vol. 5, pp. 71-127, 2003.

[23] M. Kiragu, The Prediction of Corporate Failure Using Price Adjusted Accounting Data, University of Nairobi, 1993.

[24] S. Kogi, "An Analysis of the discriminant corporate failure prediction model based on stability of financial ratios," Unpublished thesis, University of Nairobi, 2003.

[25] C. Taffler, "Alternative financial ratios as predictors of failure," Accounting Review XLIII, pp. 113-122, 2011.

[26] K. Thynne, "Test of the generalizability of Altman's bankruptcy. Prediction model," Journal of Business Research, pp. 53-61, 2006.

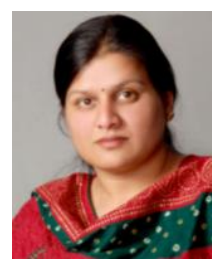

Roli Pradhan is an educator actively involved in academic writing and research. She has authored books on entrepreneur and entrepreneurship, scaling motivation. She has more than 25 international and national journals publications to her credit. She is an active reviewer for many journals. She is currently working as an assistant professor at NITTTR, Bhopal. 